\title{
Biomass and neutral lipid production in geothermal microalgal consortia
}

\author{
Kathryn F. Bywaters ${ }^{1,2}$ and Christian H. Fritsen ${ }^{1}$ * \\ 1 Division of Earth and Ecosystem Sciences, Desert Research Institute, Reno, NV, USA \\ ${ }^{2}$ Graduate Program of Environmental Science, University of Nevada Reno, Reno, NV, USA
}

\section{Edited by: \\ Umakanta Jena, Desert Research Institute, USA}

\section{Reviewed by:}

Reeta Rani Singhania, Blaise Pascal University, France

May M. Wu, Argonne National

Laboratory, USA

${ }^{*}$ Correspondence:

Christian H. Fritsen, Division of Earth and Ecosystem Sciences, Desert Research Institute, 2215 Raggio Parkway, Reno, NV 89512, USA e-mail: christian.fritsen@dri.edu

Recently, technologies have been developed that offer the possibility of using algal biomass as feedstocks to energy producing systems - in addition to oil-derived fuels (Bird et al., 2011, 2012). Growing native mixed microalgal consortia for biomass in association with geothermal resources has the potential to mitigate negative impacts of seasonally low temperatures on biomass production systems as well as mitigate some of the challenges associated with growing unialgal strains. We assessed community composition, growth rates, biomass, and neutral lipid production of microalgal consortia obtained from geothermal hot springs in the Great Basin/Nevada area that were cultured under different thermal and light conditions. Biomass production rates ranged from 39.0 to $344.1 \mathrm{mg} \mathrm{CL}^{-1} \mathrm{day}^{-1}$. The neutral lipid production in these consortia with and without shifts to lower temperatures and additions of bicarbonate (both environmental parameters that have been shown to enhance neutral lipid production) ranged from 0 to $38.74 \mathrm{mg}$ free fatty acids (FFA) and triacylglycerols (TAG) $\mathrm{L}^{-1}$ day $^{-1}$; the upper value was approximately $6 \%$ of the biomass produced. The higher lipid values were most likely due to the presence of Achnanthidium $\mathrm{sp}$. Palmitic and stearic acids were the dominant free fatty acids. The S/U ratio (the saturated to unsaturated FA ratio) decreased for cultures shifted from their original temperature to $15^{\circ} \mathrm{C}$. Biomass production was within the upper limits of those reported for individual strains, and production of neutral lipids was increased with secondary treatment. All results demonstrate a potential of culturing and manipulating resultant microalgal consortia for biomass-based energy production and perhaps even for biofuels.

\section{Keywords: algae, geothermal, biofuel, energy, biomass}

\section{INTRODUCTION}

Environmental and biological fluctuations (e.g., temperature, light levels, nutrient availability, $\mathrm{pH}$, grazers, etc.) make the maintenance of unialgal strains as a feedstock for fuels/biofuels challenging (Sheehan et al., 1998; Brennan and Owende, 2010). During the aquatic species program (ASP) that conducted a myriad of activities aimed at producing algae for oil (Sheehan et al., 1998), biomass recycling was an example of a method employed for species maintenance. Even when such measures were employed, shifts in the dominant taxa often occurred (Weissman and Benemann, 1979; Sheehan et al., 1998). Some have henceforth concluded that for successful cultivation for fuels, the best approach would be to allow a native species to invade production ponds (Sheehan et al., 1998). However, these native contaminants would have to be maintained/manipulated to be oleaginous for fuels production.

Recently, additional technologies have been developed that offer the possibility of using algal biomass as feedstocks to other energy producing systems beyond oil-derived fuels (Bird et al., 2011, 2012). Such developments make algal biomass - beyond that which is oleaginous - possible feedstocks that could help in meeting energy demands.

It is apparent that for such biomass-to-energy pathways to be developed and realized, high productivity, high yield, and low-cost-low-maintenance systems will be required. High production and yields that are able to be maintained despite timevarying conditions in temperatures and irradiances (that can vary on time scales of minutes to seasons) will be highly desirable.

Growing algal biomass in association with geothermal resources has the potential to mitigate negative impacts of low temperatures on biomass production systems - and thus, has the potential for maintaining production in areas where low seasonal temperatures might otherwise preclude high production. Moreover, cultivating microalgae in high-temperature environments has the potential to increase intrinsic growth rates and productivity. Throughout much of the arid west/southwest geothermal resources are abundant (Faulds et al., 2004) and are being further developed as a source of energy (United States Congress Senate Committee On et al., 1984). Moreover, the arid west/southwest is a location where irradiances are favorable for algal growth throughout much of the year (Davis, 2012). If water downstream from these power plants - or even directly from hot springs or wells were to be used to heat algal productions systems (either directly or indirectly), the likelihood that such systems might become viable, for use in some fashion in the algal production industry, would be expanded.

To help in the overall evaluation of the potential for growing algal biomass in high productivity systems at moderately high temperatures, we cultivated mixed consortia from two hot 
springs in Nevada, evaluated their growth at moderately high varying temperatures and then evaluated potential manipulations that could possibly increase their oleaginous production as well. Results are evaluated in context of evaluating the potential of longterm maintenance of highly productive consortia as feedstock for energy.

\section{MATERIALS AND METHODS SAMPLE COLLECTION}

Samples were collected for culturing from two geothermal hot spring sites: (1) Hazen (also known as Patua), located in central Nevada near Hwy 50 between Fernley and Fallon (39 35' 57.0 $\mathrm{N},-119^{\circ} 6^{\prime} 40.0^{\prime \prime} \mathrm{W}$ ) on 5/19/2011 and (2) Monitor (also known as Potts), located in central Nevada approximately 45 miles southeast of Austin $\left(39^{\circ} 04^{\prime} 43.3^{\prime \prime} \mathrm{N},-116^{\circ} 38^{\prime} 24.3^{\prime \prime} \mathrm{W}\right)$ on 10/29/2011. A benthic algal and sediment sample was collected at (1) Hazen at a temperature of $38^{\circ} \mathrm{C}$ and $\mathrm{pH}$ of 7.28 and (2) Monitor at a temperature of $41^{\circ} \mathrm{C}$ and $\mathrm{pH}$ of 6.87 .

Algae and nutrient samples were collected for culturing and water chemistry. Algae samples were inoculated into $3 \mathrm{~N}$ media prepared with $0.2 \mu \mathrm{m}$ capsule filtered geothermal water from each site (here after referred to as Geo3). Water samples, for chemical analysis, were filtered in situ using a $0.4-\mu \mathrm{m}$ pore polycarbonate filter and then frozen immediately until analysis. Water samples were analyzed using (1) a Lachat QuikChem FIA+ 8000 series for soluble reactive phosphorus (ortho-P), ammonium $\left(\mathrm{NH}_{4}^{+}\right)$, silicon oxide ( $\mathrm{SiOx}$ ), and total combined $\mathrm{NO}_{2}^{-}$and $\mathrm{NO}_{3}^{-}$[orthoP, 10-115-01-1-M (Liao, 2002); $\mathrm{NH}_{4}^{+}, 10-107-06-2-\mathrm{C}$ (Prokopy, 2003); SiOx, 31-114-27-1-D (Wolters, 2002); NOx, 10-107-04-1C (Pritzlaff, 2000)] and (2) a Dionex ICS-1500 ion chromatograph for the anions and cations [fluoride $\left(\mathrm{Fl}^{-}\right)$, chloride $\left(\mathrm{Cl}^{-}\right)$, bromide $\left(\mathrm{Br}^{-}\right)$, sulfate $\left(\mathrm{SO}_{4}^{2-}\right)$, lithium $\left(\mathrm{Li}^{+}\right)$, sodium $\left(\mathrm{Na}^{+}\right)$, potassium $\left(\mathrm{K}^{+}\right)$, magnesium $\left(\mathrm{Mg}^{2+}\right)$, and calcium $\left.\left(\mathrm{Ca}^{2+}\right)\right]$. Determination of anions and cations was performed using an IonPac ${ }^{\circledR}$ analytical separatory column, guard columns (anions, AS14A and AG14A; cations, CS12A and CG12A), eluents (anions, sodium carbonate, and sodium biocarbonate; cations, methane sulfanic acid), and Dionex standards (anions, Seven Anion Standard II; cations, Six Anion Standard II).

\section{INITIAL MIXED CULTURE MAINTENANCE AND EXPERIMENTAL INITIATION}

Consortia $(250 \mathrm{~mL})$ were used to inoculate $750 \mathrm{~mL}$ of media in $2 \mathrm{~L}$ baffled culture flasks. The cultures were maintained at $30^{\circ} \mathrm{C}$ (Hazen) or $40^{\circ} \mathrm{C}$ (Monitor) initially under continuous irradiance of $200 \mu \mathrm{E} \mathrm{m}^{-2} \mathrm{~s}^{-1}$, then transfered to a light:dark cycle of 12:12 hours, before being transferred to natural lighting within temperature controlled enclosures (Ecopods) in a green house setting.

\section{MIXED CULTURE SEMI-CONTINUOUS PHASE AND INCUBATION VARIANCE}

The cultures were maintained in batch mode until they reached later stages of logarithmic growth, when they were then switched to semi-continuous cultures. The volumes for the dilutions were determined by the apparent growth rates using in vivo fluorescence (Fo) measures. Fo measures were performed using a Spectromax Gemini EM 96-well plate spectrofluorometer (excitation $440 \mathrm{~nm}$, emission $680 \mathrm{~nm}$ ). During the semi-continuous phase, samples were collected and cultures were diluted with fresh media on a daily basis.

\section{GROWTH RATES}

Growth rates were determined, by Fo measures, over the time series when the culture was in the exponential growth phase using Eq. 1:

$$
\mu=\left[\ln \left(F o_{t 2}\right)-\ln \left(F o_{t 1}\right)\right] / \Delta t
$$

where $\mu$ was the growth rate, $\ln \left(\mathrm{Fo}_{\mathrm{t} 2}\right)$ was the natural log of the Fo reading at the end of the determined growth phase, $\ln \left(\mathrm{Fo}_{\mathrm{t} 1}\right)$ was the natural log of the Fo reading at the beginning of the determined growth phase, and $\Delta t$ was the time interval. The upper and lower limits were determined by a $95 \%$ confidence interval on the natural log of the exponential growth phase. $P$-values were generated and all values were below the critical value 0.05 .

The microalgal consortia sub-cultures were taken and transferred to three separate incubation conditions. The incubation conditions for Hazen samples were natural light in a greenhouse (EcoPod - EP) at (1) $30 \pm 3^{\circ} \mathrm{C}$, (2) $35 \pm 2^{\circ} \mathrm{C}$, and (3) $40 \pm 3^{\circ} \mathrm{C}$. The incubation conditions for Monitor samples were EP at (1) $35 \pm 2^{\circ} \mathrm{C}$, (2) $40 \pm 3^{\circ} \mathrm{C}$, and (3) $45 \pm 3^{\circ} \mathrm{C}$. After the cultures had acclimated to their respective conditions they were maintained in a semi-continuous state (Figure 1).

\section{MIXED CULTURE SECONDARY TREATMENT}

When a near steady-state was obtained, mixed cultures were combined and then split into 12 separate $\times 500 \mathrm{~mL}$ culture flasks for a given incubation condition. From the 12 replicates, 4 treatments (3 replicates per treatment) were achieved and each treatment was either: maintained at temperature, maintained at temperature with the addition of sodium bicarbonate (final concentration $4 \mathrm{mM}$ ), incubated at $15^{\circ} \mathrm{C}$, or incubated at $15^{\circ} \mathrm{C}$ with the addition of sodium bicarbonate (final concentration $4 \mathrm{mM}$ ) - with the exception of the $40^{\circ} \mathrm{C}$ Hazen cultures that only underwent the temperature shift and the temperature shift with the addition of bicarbonate.

All mixed cultures were incubated for a 5-day period. Samples were taken daily for microscopy (fixed with glutaraldehyde $0.5 \%$ final concentration), measures of Fo, and stained with Nile Red (NR) for quantification of neutral lipids ( $15 \mu \mathrm{L}$ of NR solution was added to $1 \mathrm{~mL}$ algal suspension, vortexed and $300 \mu \mathrm{L}$ loaded into wells of a 96-well plate; fluorescence intensity was measured using a Spectromax Gemini EM 96-well plate spectrofluorometer: excitation $530 \mathrm{~nm}$ and emission $575 \mathrm{~nm}$ ). Samples for measures of water chemistry, triacylglycerides (TAG), free fatty acids (FFA), and ash free dry weight (AFDW) were taken at the beginning and end of the 5-day period. AFDW samples were vacuum filtered onto pre-combusted $\left(500^{\circ} \mathrm{C}\right.$ for $\left.1 \mathrm{~h}\right) \mathrm{GF} / \mathrm{F}$ filters, dried, and stored with desiccant. AFDW was then determined gravimetrically using standard methods (Clesceri et al., 1998). TAG and FFA samples were analyzed using electrospray tandem mass spectrometry (ESI-MS/MS) and ultra-performance liquid chromatography-tandem mass spectrometric (UPLC/MS) methods (Samburova et al., 2013). 


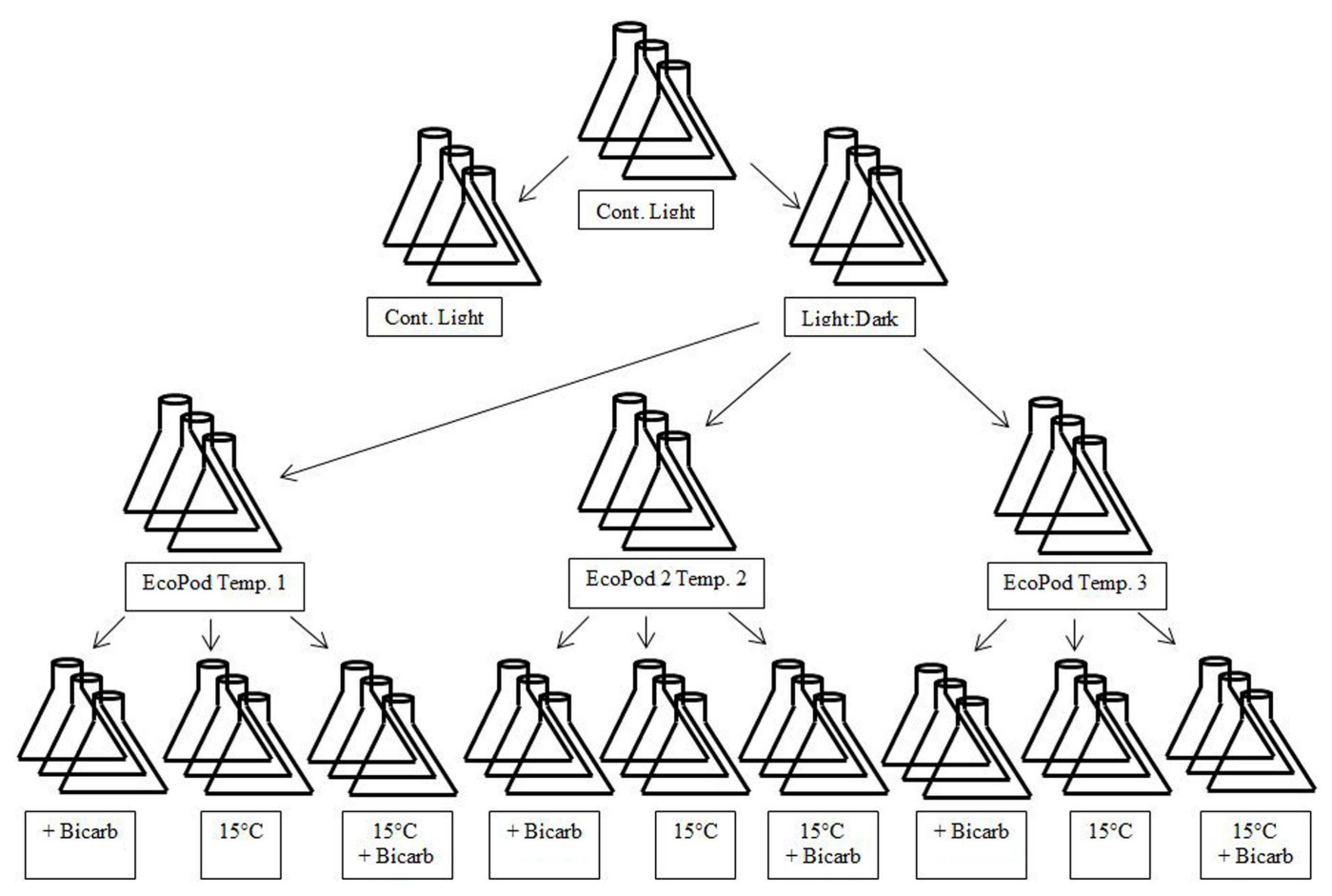

FIGURE 1 | Diagram of experimental design matrix. EcoPods (incubators in a greenhouse) were maintained at three different temperatures for each culture - Hazen: $30 \pm 3^{\circ} \mathrm{C}, 35 \pm 2{ }^{\circ} \mathrm{C}$, and $40 \pm 3^{\circ} \mathrm{C}$ and Monitor: $35 \pm 2{ }^{\circ} \mathrm{C}, 40 \pm 3^{\circ} \mathrm{C}$, and $45 \pm 3^{\circ} \mathrm{C}$. Secondary treatments consisted of the addition of bicarbonate, a shift to $15^{\circ} \mathrm{C}$ and a shift to $15^{\circ} \mathrm{C}$ with the addition of bicarbonate

Table 1 | Chemical composition of geothermal hot springs water from Hazen and Monitor hot springs.

\begin{tabular}{|c|c|c|c|c|c|c|c|c|c|c|c|c|c|}
\hline Site & $\begin{array}{l}\text { Ortho-P } \\
(\mu \mathrm{M})\end{array}$ & $\begin{array}{l}\mathrm{NH}_{4} \\
(\mu \mathrm{M})\end{array}$ & $\begin{array}{l}\text { SiOx } \\
(\mu \mathrm{M})\end{array}$ & $\begin{array}{l}\mathrm{NO}_{2}+\mathrm{NO}_{3} \\
(\mu \mathrm{M})\end{array}$ & $\begin{array}{l}\mathrm{Li}^{+} \\
(\mu \mathrm{M})\end{array}$ & $\begin{array}{l}\mathrm{Na}^{+} \\
(\mu \mathrm{M})\end{array}$ & $\begin{array}{l}\mathbf{K}^{+} \\
(\mu \mathrm{M})\end{array}$ & $\begin{array}{l}\mathbf{M g}^{2+} \\
(\mu \mathrm{M})\end{array}$ & $\begin{array}{l}\mathrm{Ca}^{2+} \\
(\mu \mathrm{M})\end{array}$ & $\begin{array}{l}\mathrm{FI}^{-} \\
(\mu \mathrm{M})\end{array}$ & $\begin{array}{l}\mathrm{Cl}^{-} \\
(\mu \mathrm{M})\end{array}$ & $\begin{array}{l}\mathrm{Br}^{-} \\
(\mu \mathrm{M})\end{array}$ & $\begin{array}{l}\mathrm{SO}_{4}^{2-} \\
(\mu \mathrm{M})\end{array}$ \\
\hline Hazen & 1.29 & 14.55 & 1560.14 & 0.61 & 260.93 & 28248.66 & 989.30 & 26.98 & 1789.47 & 247.23 & 25163.14 & 36.13 & 3751.43 \\
\hline
\end{tabular}

\section{BIOMASS, TAG, AND FFA DETERMINATIONS}

Biomass, TAG, and FFA production rates were determined using the ADFW data. Biomass productivity was determined by AFDW at the beginning and end of the growth phase over the time of the growth phase (estimates of carbon production were made using an average C:AFDW ratio of $0.5 \mathrm{~g}: \mathrm{g}$ ). The concentration of TAG and FFA (determined by ESI-MS/MS and UPLC/MS methods) for each sample was divided by the AFDW, for that sample, to determine the total TAG and FFA content per unit biomass.

\section{RESULTS}

\section{CHEMICAL COMPOSITION OF GEOTHERMAL WATERS}

The chemical composition of the geothermal hot spring waters Hazen and Monitor - was different; the majority of cation and anion concentrations in Hazen water were considerably higher (Table 1). Sodium was over 13 times higher in Hazen than Monitor water. Cations: lithium, potassium, and calcium were also higher in Hazen water, except magnesium, which was almost four times higher in Monitor water. Silica, nitrate plus nitrite, and phosphorous were higher in Hazen, as well.

\section{CULTURE EXPERIMENTS - EcoPods AND SECONDARY TREATMENT Community composition}

The dominant taxa of the Hazen geothermal consortia, at 30, 35, and $40^{\circ} \mathrm{C}$, were similar and consisted of Achnanthidium sp., Aphanocapsa sp., Synechocystis sp., and Leptolyngbya sp (Tables 2-4). The algal assemblage at the beginning and end of the treatment period was consistent for replicates of a specific treatment. Shifts in the dominant algal genus in the consortia, were seen at $30^{\circ} \mathrm{C}$ with the addition of bicarbonate, at $35^{\circ} \mathrm{C}$, and at $35^{\circ} \mathrm{C}$ with the addition of bicarbonate. Dominance in the assemblages shifted from Achnanthidium sp. to either Synechocystis sp. or Leptolyngbya sp.

Dominant taxa in the Monitor geothermal consortia, at 35, 40 , and $45^{\circ} \mathrm{C}$, were similar and consisted of Oscillatorian sp., Synechocystis sp., and Leptolyngbya sp. at the beginning of the secondary treatment phase. The algal assemblage at the beginning 
Table 2 | Relative percentage of dominate taxa by biovolume for the EcoPod (natural light) cultures at $30^{\circ} \mathrm{C}$ before and after secondary treatment; $N=3$ for all counts, \pm 1 SD.

\begin{tabular}{|c|c|c|c|c|c|c|}
\hline & $\begin{array}{l}\text { EP30 } \\
6 / 28\end{array}$ & $\begin{array}{l}\text { EP30 } \\
8 / 22\end{array}$ & $\begin{array}{c}\text { EP30/30 } \\
8 / 27\end{array}$ & $\begin{array}{c}E P 30 / 30+B \\
8 / 27\end{array}$ & $\begin{array}{c}\text { EP30/15 } \\
8 / 27\end{array}$ & $\begin{array}{c}E P 30 / 15+B \\
8 / 27\end{array}$ \\
\hline Leptolyngbya & $0 \pm 0$ & $5 \pm 1$ & $3 \pm 0$ & $20 \pm 3$ & $9 \pm 1$ & $8 \pm 1$ \\
\hline Aphanocapsa & $26 \pm 6$ & $22 \pm 4$ & $24 \pm 7$ & $10 \pm 1$ & $29 \pm 2$ & $27 \pm 2$ \\
\hline Synechocystis & $34 \pm 11$ & $34 \pm 16$ & $43 \pm 17$ & $52 \pm 4$ & $53 \pm 11$ & $46 \pm 18$ \\
\hline Achnanthidium & $34 \pm 12$ & $25 \pm 13$ & $22 \pm 13$ & $1 \pm 1$ & $4 \pm 4$ & $15 \pm 13$ \\
\hline Chroococcus & $6 \pm 5$ & $15 \pm 3$ & $7 \pm 5$ & $18 \pm 10$ & $5 \pm 5$ & $5 \pm 7$ \\
\hline Synechococcus & $0 \pm 0$ & $0 \pm 0$ & $0 \pm 0$ & $0 \pm 0$ & $0 \pm 0$ & $1 \pm 1$ \\
\hline
\end{tabular}

Table 3 | Relative percentage of dominate taxa by biovolume for the EcoPod (natural light) cultures at $35^{\circ} \mathrm{C}$ before and after secondary treatment; $N=3$ for all counts, \pm 1 SD.

\begin{tabular}{|c|c|c|c|c|c|c|}
\hline & $\begin{array}{l}\text { EP35 } \\
7 / 18\end{array}$ & $\begin{array}{l}\text { EP35 } \\
8 / 22\end{array}$ & $\begin{array}{c}\text { EP35/35 } \\
8 / 27\end{array}$ & $\begin{array}{c}E P 35 / 35+B \\
8 / 27\end{array}$ & $\begin{array}{c}\text { EP35/15 } \\
8 / 27\end{array}$ & $\begin{array}{c}E P 35 / 15+B \\
8 / 27\end{array}$ \\
\hline Leptolyngbya & $0 \pm 0$ & $13 \pm 3$ & $44 \pm 13$ & $16 \pm 5$ & $29 \pm 4$ & $20 \pm 9$ \\
\hline Aphanocapsa & $53 \pm 24$ & $56 \pm 8$ & $35 \pm 9$ & $29 \pm 2$ & $40 \pm 11$ & $53 \pm 5$ \\
\hline Synechocystis & $24 \pm 21$ & $15 \pm 3$ & $13 \pm 3$ & $51 \pm 10$ & $0 \pm 0$ & $0 \pm 0$ \\
\hline Achnanthidium & $18 \pm 18$ & $16 \pm 3$ & $8 \pm 2$ & $4 \pm 1$ & $31 \pm 2$ & $27 \pm 7$ \\
\hline Chroococcus & $0 \pm 0$ & $0 \pm 0$ & $0 \pm 0$ & $0 \pm 0$ & $0 \pm 0$ & $0 \pm 0$ \\
\hline Synechococcus & $4 \pm 5$ & $0 \pm 0$ & $0 \pm 0$ & $0 \pm 0$ & $0 \pm 0$ & $0 \pm 0$ \\
\hline
\end{tabular}

Table 4 | Relative percentage of dominate taxa by biovolume for the EcoPod (natural light) cultures at $40^{\circ} \mathrm{C}$ before and after secondary treatment; $N=3$ for all counts, \pm 1 SD.

\begin{tabular}{lcccc}
\hline & EP40 & EP40 & EP40/15 & EP40/15+ B \\
& $\mathbf{7 / 2 8}$ & $\mathbf{8 / 2 2}$ & $\mathbf{8 / 2 7}$ & $\mathbf{8 / 2 7}$ \\
\hline Leptolyngbya & $0 \pm 0$ & $19 \pm 5$ & $7 \pm 1$ & $9 \pm 1$ \\
Aphanocapsa & $21 \pm 5$ & $39 \pm 15$ & $31 \pm 5$ & $52 \pm 12$ \\
Synechocystis & $45 \pm 14$ & $11 \pm 4$ & $61 \pm 25$ & $38 \pm 6$ \\
Achnanthidium & $21 \pm 20$ & $2 \pm 2$ & $0 \pm 0$ & $0 \pm 0$ \\
Chroococcus & $12 \pm 21$ & $0 \pm 0$ & $0 \pm 0$ & $0 \pm 0$ \\
Synechococcus & $1 \pm 1$ & $29 \pm 11$ & $1 \pm 2$ & $2 \pm 2$
\end{tabular}

and end of the treatment period were consistent for replicates of a specific treatment. Shifts in the dominant genus in the consortia were seen at $45^{\circ} \mathrm{C}$ with and without the addition of bicarbonate to Leptolyngbya dominated assemblages.

\section{Specific growth rates}

Hazen. Cultures maintained at temperature with the addition of bicarbonate had higher growth rates (ranging from 0.63 to 0.79 doublings day $^{-1}$ ) than those just maintained at temperature (ranging from 0.46 to 0.60 doublings day ${ }^{-1}$ ). The highest growth rate was observed in the cultures at $30^{\circ} \mathrm{C}$ with the addition of bicarbonate, averaging 0.79 doublings day ${ }^{-1}$. The temperature shift to $15^{\circ} \mathrm{C}$ decreased the growth rates in all cultures, and in some cases to a growth rate of 0 (Figure 2; Table 5).

Monitor. Cultures maintained at temperature with the addition of bicarbonate had higher growth rates (ranging from 0.29 to
0.62 doublings day $^{-1}$ ) than those just maintained at temperature (ranging from 0.21 to 0.50 doublings day ${ }^{-1}$ ). The highest growth rate was achieved by the cultures at $40^{\circ} \mathrm{C}$ with the addition of bicarbonate, averaging 0.62 doublings day ${ }^{-1}$. The temperature shift to $15^{\circ} \mathrm{C}$ decreased the growth rates in all cultures, and in some case to a growth rate of 0 (Figure 3; Table 5).

\section{Biomass productivity}

Hazen. Biomass productivity followed the same trends as the measured growth rates. The cultures maintained at $30^{\circ} \mathrm{C}$ with the addition of bicarbonate produced the greatest biomass $344.1 \mathrm{mg} \mathrm{C} \mathrm{L}^{-1} \mathrm{day}^{-1}$. The culture at $35^{\circ} \mathrm{C}$ had the lowest biomass production $-118.9 \mathrm{mg} \mathrm{C} \mathrm{L}^{-1} \mathrm{day}^{-1}$. The cultures maintained at temperature (excluding $45^{\circ} \mathrm{C}$ ) - with the addition of bicarbonate had an average percent increase in biomass production of $163 \%$ more than the cultures that did not have bicarbonate additions (Table 5).

Monitor. Biomass productivity also followed the same trends as the measured growth rates. The cultures maintained at $40^{\circ} \mathrm{C}$ with the addition of bicarbonate produced the greatest biomass $-382.3 \mathrm{mg} \mathrm{C} \mathrm{L}^{-1} \mathrm{day}^{-1}$. The culture at $45^{\circ} \mathrm{C}$ had the lowest biomass production $-39.0 \mathrm{mg} \mathrm{C} \mathrm{L}^{-1} \mathrm{day}^{-1}$. The cultures maintained at temperature - with the addition of bicarbonate had an average percent increase in biomass production of $102 \%$ more than the cultures that did not have bicarbonate additions (Table 5).

\section{Nile Red, FFA, and TAGs productivity and composition}

The NR values showed an average increase in neutral lipid accumulation per unit biomass of only $6-8 \%$ with secondary treatments 

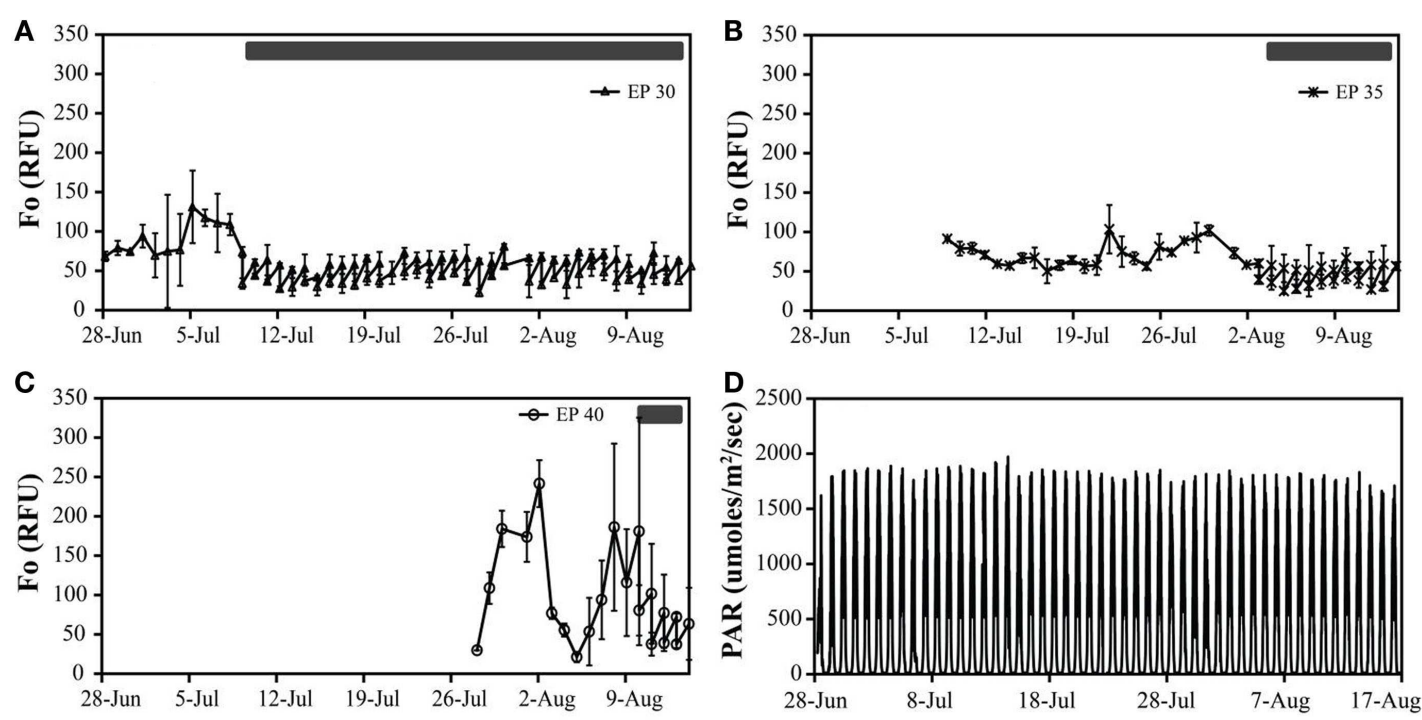

FIGURE 2 |The in vivo fluorescence (relative fluorescence units - RFU) of Hazen geothermal consortia at different

incubation conditions: EcoPod at $30^{\circ} \mathrm{C}$ (EP 30) with dilution rates of $60 \%$ from July 9 th through August 14 th $(\mathbf{A})$, EcoPod at $35^{\circ} \mathrm{C}$ (EP 35)

with dilution rates of $50 \%$ from August 3rd through 14th (B), EcoPod at $40^{\circ} \mathrm{C}$ (EP 40) with dilution rates of $45 \%$ from August 10th through 14th (C). PAR measured in $\mu$ moles $\mathrm{m}^{-2} \mathrm{~s}^{-1}$ for the duration of the experiment (D).

Table 5 | Growth rates, triacylglycerides (TAG), and free fatty acids (FFA), biomass production rates of Hazen and Monitor consortia incubated at different temperatures with and without the addition of bicarbonate

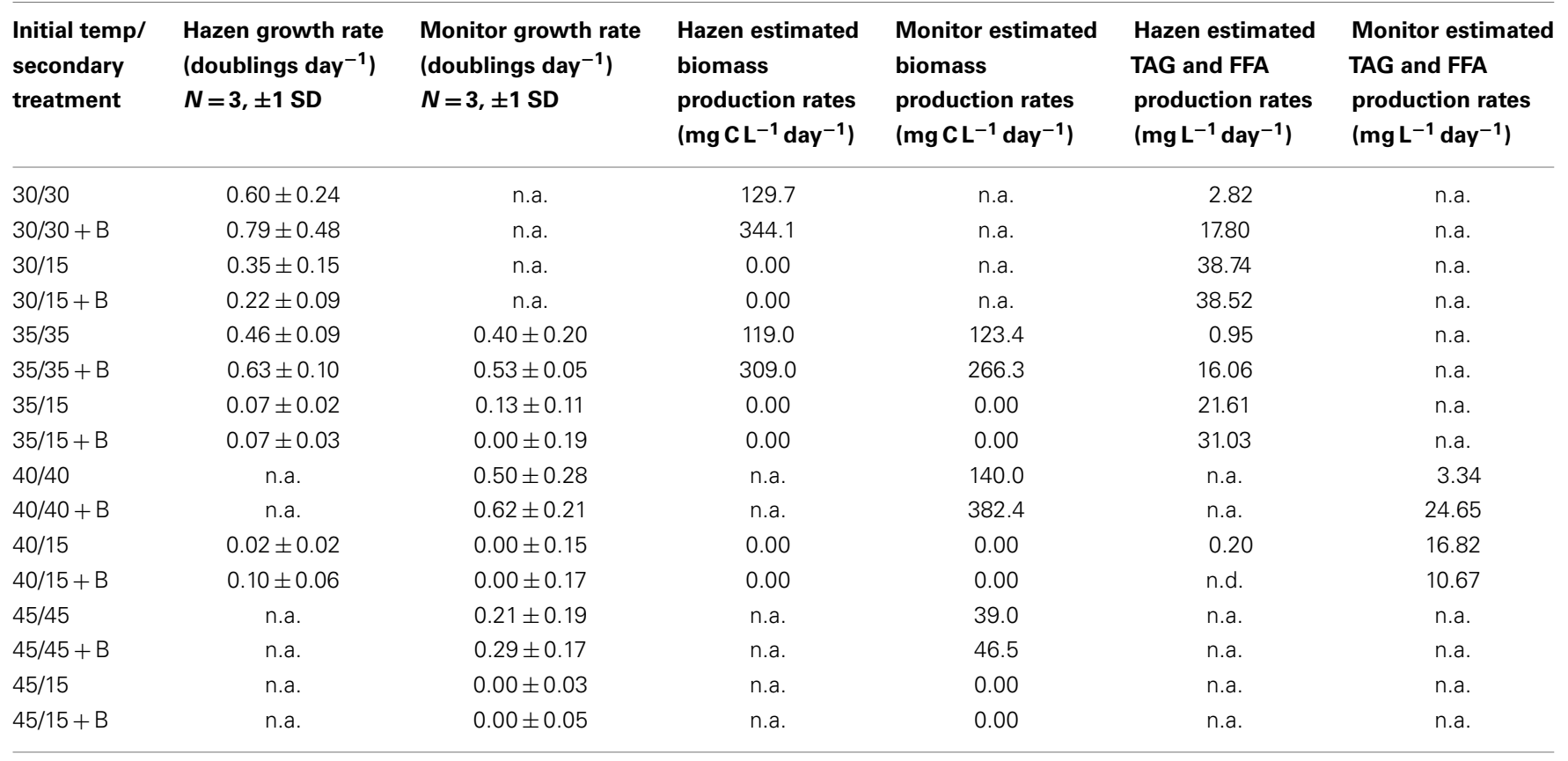

n.a., not applicable; n.d., not detected.

(except $40^{\circ} \mathrm{C}$, which actually showed a decrease) (Figure 4 ). The change in Nile Red values in the biomass was similar to the trends observed in TAG and FFA accumulation.

The FFA and TAG concentration per amount of biomass, for the Hazen cultures, marginally increased with the addition of bicarbonate - from approximately $1-3 \%$. The addition of bicarbonate, for cultures maintained at temperature, increased the estimated FFA and TAG productivity from (1) 2.82 to $17.8 \mathrm{mg} \mathrm{L}^{-1} \mathrm{day}^{-1}$ for $30^{\circ} \mathrm{C}$ and (2) 0.95 to $16.06 \mathrm{mg} \mathrm{L}^{-1} \mathrm{day}^{-1}$ for $35^{\circ} \mathrm{C}$ (Table 5). The amount of FFA and TAG per amount biomass increased with decreasing temperature by $3-5 \%$ - except in the $40^{\circ} \mathrm{C}$ cultures (Figure 4 ). 

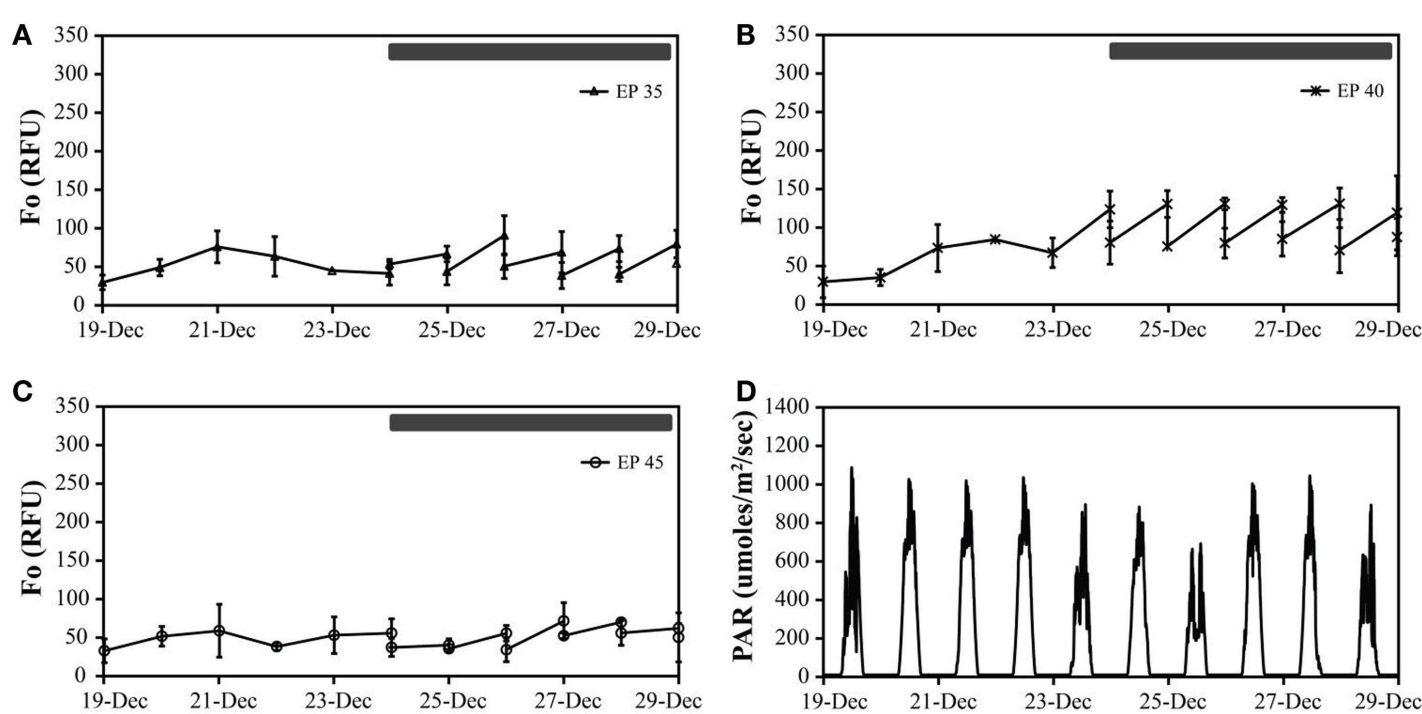

FIGURE 3 |The in vivo fluorescence of Monitor geothermal consortia at different incubation conditions: EcoPod at $35^{\circ} \mathrm{C}$ (EP 35) with dilution rates of $40 \%$ from December 24th through 29th (A), EcoPod at $40^{\circ} \mathrm{C}$ (EP 40) with dilution rates of $50 \%$ from December 24th through 29th (B), EcoPod at $45^{\circ} \mathrm{C}$ (EP 45) with dilution rates of $20 \%$ from December 24 th through 29 th (C). PAR measured in $\mu$ moles $\mathrm{m}^{-2} \mathrm{~s}^{-1}$ for the duration of the experiment (D).
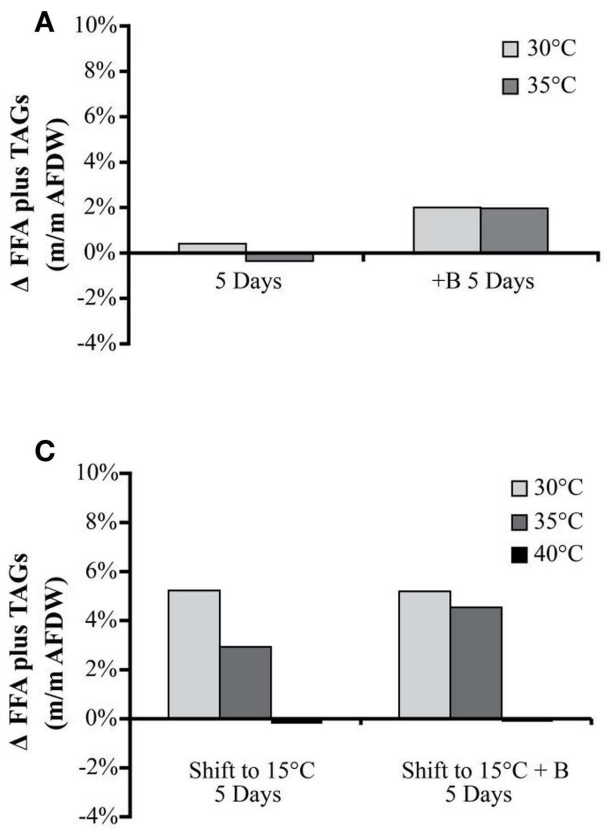

FIGURE 4 | Hazen geothermal consortia: change of FFA and TAG $(\%, w / w)$ after 5 days, with and without the addition of bicarbonate (A), change of NR after 5 days with and without the

A decrease in temperature increased the estimated FFA and TAG productivity, to $21.61-38.74 \mathrm{mg} \mathrm{L}^{-1}$ day $^{-1}$. The Monitor cultures showed an increase in TAG and FFA per amount biomass with both the addition of bicarbonate and a temperature drop (from $3.34 \mathrm{mg} \mathrm{L}^{-1} \mathrm{day}^{-1}$ to a maximum value of $24.65 \mathrm{mg} \mathrm{L}^{-1}$ day $\left.^{-1}\right)$.
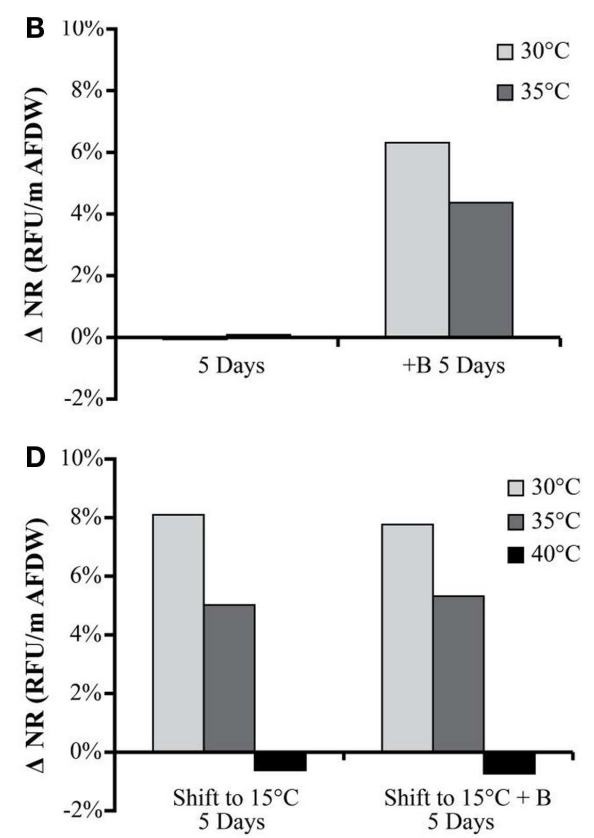

addition of bicarbonate (B), as well as a shift to $15^{\circ} \mathrm{C}$ from their original incubation conditions with and without the addition of bicarbonate (C,D).

FFA and TAG profiles were analyzed for the following treatment conditions: (1) maintained at temperature, (2) maintained at temperature with the addition of bicarbonate, (3) shifted to $15^{\circ} \mathrm{C}$, and $(4)$ shifted to $15^{\circ} \mathrm{C}$ with the addition of bicarbonate. FFA composition stayed relatively constant with both the addition of bicarbonate and with the temperature shift (Table 6). The TAG 
Table 6 |The composition of FFA in Hazen geothermal consortia (\%, w/w) at 0 and 5 days, with and without the addition of bicarbonate (A) as well as a shift to $15^{\circ} \mathrm{C}$ from their original incubation conditions, with and without the addition of bicarbonate (B)

\begin{tabular}{|c|c|c|c|c|c|c|c|c|c|c|}
\hline \multirow[t]{2}{*}{ Free fatty acid } & \multicolumn{4}{|c|}{0 Days } & \multicolumn{3}{|c|}{5 Days } & \multicolumn{3}{|c|}{5 Days + Bicarb } \\
\hline & & $30^{\circ} \mathrm{C}$ & & $35^{\circ} \mathrm{C}$ & & & $35^{\circ} \mathrm{C}$ & $30^{\circ} \mathrm{C}$ & & $35^{\circ} \mathrm{C}$ \\
\hline \multicolumn{11}{|l|}{ (A) } \\
\hline Linolenic acid C18:3 & & 0.5 & & 0.4 & & & 1.0 & n.d. & & 1.1 \\
\hline Linoleic acid C18:2 & & 1.6 & & 2.9 & & & 2.9 & 0.6 & & 2.7 \\
\hline Palmitic acid C16:0 & & 29.7 & & 26.5 & & & 20.3 & 29.6 & & 18.6 \\
\hline Palmitoleic acid C16:1 & & 17.7 & & 19.6 & & & 28.4 & 15.1 & & 40.8 \\
\hline Oleic acid C18:1 & & 4.7 & & 5.7 & & & 8.7 & 3.9 & & 8.0 \\
\hline Hexadecatrienoic acid C16:3 & & n.d. & & n.d. & & & n.d. & n.d. & & n.d. \\
\hline Hexadecadienoic acid C16:2 & & 1.6 & & 1.6 & & & 3.2 & n.d. & & 0.6 \\
\hline Stearic acid C18:0 & & 42.7 & & 36.3 & & & 21.9 & 50.3 & & 17.0 \\
\hline Arachidonic acid C20:4 & & 1.6 & & 6.5 & & & 13.2 & 0.6 & & 11.1 \\
\hline Eicosadienoic acid C20:2 & & n.d. & & 0.4 & & & 0.3 & n.d. & & n.d. \\
\hline Eicosenoic acid C20:1 & & n.d. & & n.d. & & & n.d. & n.d. & & n.d. \\
\hline \multirow[t]{3}{*}{ Free fatty acid } & & & & & \multicolumn{3}{|c|}{$15^{\circ} \mathrm{C}$ Shift } & \multicolumn{3}{|c|}{$15^{\circ} \mathrm{C}$ Shift } \\
\hline & \multicolumn{4}{|c|}{0 Days } & \multicolumn{3}{|c|}{5 Days } & \multicolumn{3}{|c|}{5 Days + Bicarb } \\
\hline & $30^{\circ} \mathrm{C}$ & & $35^{\circ} \mathrm{C}$ & $40^{\circ} \mathrm{C}$ & $30^{\circ} \mathrm{C}$ & $35^{\circ} \mathrm{C}$ & $40^{\circ} \mathrm{C}$ & $30^{\circ} \mathrm{C}$ & $35^{\circ} \mathrm{C}$ & $40^{\circ} \mathrm{C}$ \\
\hline \multicolumn{11}{|l|}{ (B) } \\
\hline Linolenic acid C18:3 & 0.5 & & 0.4 & n.d. & 5.9 & 1.9 & n.d. & 5.7 & 5.2 & n.d. \\
\hline Linoleic acid C18:2 & 1.6 & & 2.9 & 1.6 & 5.5 & 2.5 & 10.1 & 4.6 & 6.4 & 11.4 \\
\hline Palmitic acid C16:0 & 29.7 & & 26.5 & 32.4 & 12.8 & 17.3 & 26.8 & 12.5 & 13.1 & 24.0 \\
\hline Palmitoleic acid C16:1 & 17.7 & & 19.6 & 7.6 & 39.8 & 48.6 & 6.1 & 40.8 & 38.0 & 15.3 \\
\hline Oleic acid C18:1 & 4.7 & & 5.7 & 5.9 & 7.3 & 3.4 & 14.5 & 7.3 & 7.1 & 13.1 \\
\hline Hexadecatrienoic acid C16:3 & n.d. & & n.d. & n.d. & 0.4 & 0.1 & n.d. & 0.4 & 0.3 & n.d. \\
\hline Hexadecadienoic acid C16:2 & 1.6 & & 1.6 & n.d. & 9.2 & 4.3 & n.d. & 9.4 & 9.0 & n.d. \\
\hline Stearic acid C18:0 & 42.7 & & 36.3 & 52.4 & 5.9 & 16.8 & 42.5 & 7.9 & 10.1 & 36.2 \\
\hline Arachidonic acid C20:4 & 1.6 & & 6.5 & n.d. & 12.8 & 4.8 & n.d. & 11.1 & 10.3 & n.d. \\
\hline Eicosadienoic acid C20:2 & n.d. & & 0.4 & n.d. & 0.4 & 0.2 & n.d. & 0.2 & 0.4 & n.d. \\
\hline Eicosenoic acid C20:1 & n.d. & & n.d. & n.d. & 0.1 & 0.1 & n.d. & 0.1 & 0.1 & n.d. \\
\hline
\end{tabular}

n.d., limit of detection $\left(0.03 \mu \mathrm{gmL}^{-1}\right)$.

diversity increased after the fifth day of the incubation period in all cultures. A shift was seen in the TAG composition to a decrease in chain length and increase in unsaturation at the cooler temperatures (Table 7).

\section{DISCUSSION}

Owing to the potential for energy production, it is imperative to determine algal consortia production rate of biomass and lipids, from high-temperature environments under culturing conditions. Cultivation conditions, such as temperatures and secondary treatment, can maximize production rates of algal biomass or increase neutral lipid concentrations. Microalgal consortia collected from naturally high-temperature environments present the possibility of robust communities, potentially having the advantage of resistance to invasion in production systems, and for elevated growth rates - therefore, biomass. Growing algae at higher temperature requires more energy to maintain; however, coupling this system with a geothermal resource would reduce energy requirements for heating and have the added bonus of consistent temperatures in all seasons. High biomass production rate were obtained from geothermal microalgal consortia.

Biomass production rate were similar for both Hazen and Monitor cultures over the range of temperature treatments (except Monitor at $45^{\circ} \mathrm{C}$, which had $<50 \%$ the production rate of the other cultures). Microalgae have evolved so that their optimum temperature is the same as their environmental temperature (Brock, 1967), which would explain why increasing the incubation temperature did not increase biomass production rates.

Biomass production rates (39.0-344.1 $\mathrm{mg} \mathrm{C} \mathrm{L}^{-1} \mathrm{day}^{-1}$ ) achieved by geothermal microalgal consortia (Hazen/Monitor) were comparable to those reported for individual strains. The reported biomass production rates of various strains (taxa and incubation temperature: Nannochloropsis sp. $28 \pm 1^{\circ} \mathrm{C}$, Isochrysis sp. $22 \pm 2^{\circ} \mathrm{C}$, Tetraselmis sp. $28 \pm 1^{\circ} \mathrm{C}$, Neochloris oleoabundans $25.6^{\circ} \mathrm{C}$, Chlorella sp. $23-29^{\circ} \mathrm{C}$, Dunaliella salina $23-29^{\circ} \mathrm{C}$, and Chlorella vulgaris $23-$ $29^{\circ} \mathrm{C}$ ) range from 42.3 to $7100 \mathrm{mg} \mathrm{C} \mathrm{L}^{-1} \mathrm{day}^{-1}$ (Huerlimann et al., 
Table 7 | The composition of TAG in Hazen geothermal consortia (\%, w/w) at $\mathbf{0}$ and $\mathbf{5}$ days, with and without the addition of bicarbonate (A) as well as a shift to $15^{\circ} \mathrm{C}$ from their original incubation conditions, with and without the addition of bicarbonate (B).

\begin{tabular}{|c|c|c|c|c|c|c|}
\hline TAG & \multicolumn{2}{|c|}{0 Days } & \multicolumn{2}{|c|}{5 Days } & \multicolumn{2}{|c|}{5 Days + Bicarb } \\
\hline C16:1/C16:1/C16:1 & n.d. & n.d. & 10.8 & 10.0 & 16.9 & 10.4 \\
\hline C16:0/C16:1/C16:1 & n.d. & 25.0 & 35.0 & 34.6 & 34.1 & 34.5 \\
\hline C16:0/C16:0/C16:1 & n.d. & 25.0 & 26.8 & 28.5 & 22.9 & 24.7 \\
\hline C18:3/C16:1/C16:0 & n.d. & n.d. & 1.9 & 2.3 & 1.7 & 1.7 \\
\hline C18:3/C16:0/C16:0 & n.d. & n.d. & 3.2 & 3.8 & 4.1 & 3.4 \\
\hline C18:1/C16:1/C16:0 & n.d. & n.d. & 5.1 & 5.4 & 6.9 & 6.3 \\
\hline C18:1/C16:0/C16:0 & n.d. & n.d. & 3.2 & 3.1 & 3.3 & 3.1 \\
\hline C18:0/C16:0/C16:0 & n.d. & n.d. & n.d. & n.d. & 0.1 & 0.1 \\
\hline C18:1/C18:1/C16:0 & n.d. & n.d. & 0.6 & 0.8 & 0.3 & 0.3 \\
\hline C18:1/C18:0/C16:0 & n.d. & n.d. & 0.6 & n.d. & 0.2 & 0.2 \\
\hline C18:0/C18:0/C16:0 & n.d. & n.d. & n.d. & n.d. & n.d. & n.d. \\
\hline C18:0/C18:1/C18:3 & n.d. & n.d. & n.d. & n.d. & 0.2 & 0.2 \\
\hline C18:1/C18:1/C18:1 & n.d. & n.d. & 0.6 & 0.8 & 0.1 & 0.2 \\
\hline C18:0/C18:1/C18:1 & n.d. & n.d. & n.d. & n.d. & 0.1 & 0.1 \\
\hline C18:0/C18:0/C18:1 & 100.0 & 50.0 & 1.3 & 1.5 & 0.3 & 0.1 \\
\hline C20:4/C18:1/C16:2 & n.d. & n.d. & n.d. & n.d. & 0.3 & 0.2 \\
\hline
\end{tabular}

TAG

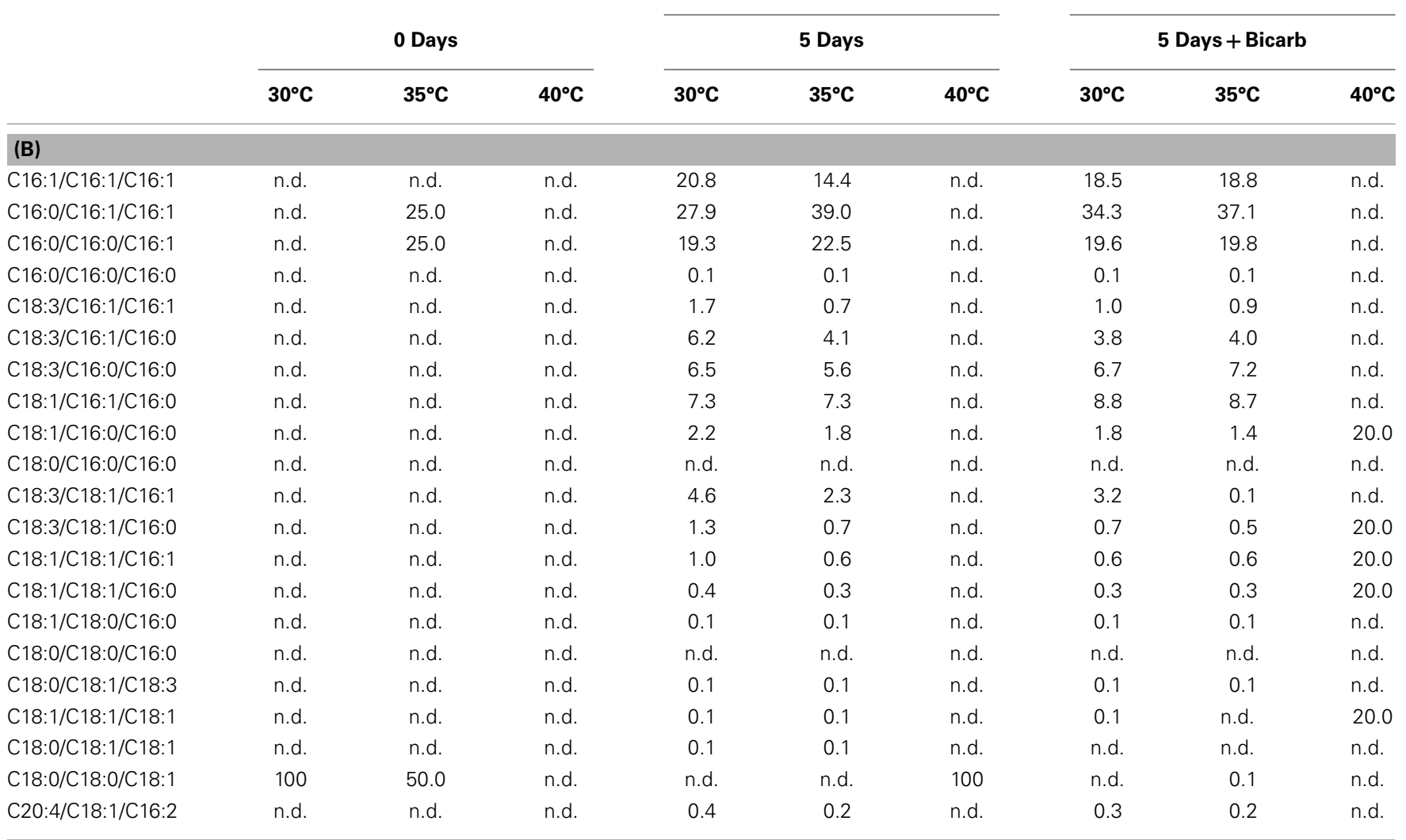

$15^{\circ} \mathrm{C}$ Shift

$15^{\circ} \mathrm{C}$ Shift

5 Days + Bicarb

$15^{\circ} \mathrm{C}$ Shift


2010; Araujo et al., 2011; Kim, 2011; Zhou et al., 2011; Murray et al., 2012). The incubation temperatures for the strains reported in the literature were mainly below those that were used in this experiment. The production rates, with the addition of bicarbonate, were enhanced. The addition of bicarbonate allows for enhanced inorganic carbon uptake to produce cellular material and thereby achieving maximum productivity. The poor solubility of $\mathrm{CO}_{2}$ in water $\left(1.25 \mathrm{~g} \mathrm{~kg}^{-1}\right.$ water at $30^{\circ} \mathrm{C}$ and $\left.1 \mathrm{~atm}\right)$ can lead to growth inhibition due to carbon limitations (Smith and Bidwell, 1989; Giordano et al., 2005; Aishvarya et al., 2012). $\mathrm{CO}_{2}$ solubility decreases with increasing temperature and at higher temperature ranges there can be severe loss of gaseous $\mathrm{CO}_{2}$ in aquatic systems (Dodds et al., 1956; Carroll et al., 1991). Given what is known about $\mathrm{CO}_{2}$ solubility it is logical to propose that geothermal systems might be carbon limited (due to being at elevated temperatures); the demonstrated increase in biomass production with the addition of bicarbonate further supports this hypothesis. The result of higher biomass production validates the idea that biomass yields can be increased with the utilization of native geothermal consortia.

Biomass production ranged from approximately 3.8$34.5 \mathrm{~g} \mathrm{C} \mathrm{m}^{-2}$ day $^{-1}$ with the addition of bicarbonate. The longterm industry standard, set by U.S. Department of Energy's Aquatic Species Program, for biomass production from microalgae is $50 \mathrm{~g}$ dry weight $\mathrm{m}^{-2}$ day $^{-1}$ to be cost effective and competitive with fossil fuels (Sheehan et al., 1998). Production rates were converted from a volume basis (L) to an area production bases $\left(\mathrm{m}^{2}\right)$ assuming that volumetric bases can be maintained in a raceway pond at a height of $30 \mathrm{~cm}$ - optimal depth for an open-race way pond for comparison to the industrial standard (Sheehan et al., 1998). The majority of open-race way ponds range from 10 to $50 \mathrm{~cm}$ in depth. The shallow depths used in cultivation have several advantages: (1) effective utilization of mixing energy, (2) less concentration needed at harvesting, and (3) dense cultures maintain photosynthetic efficiency because at deeper depths light becomes attenuated due to self-shading (Terry and Raymond, 1985; Sheehan et al., 1998; Brennan and Owende, 2010; Stephenson et al., 2011). However, the production rates are based on the experimental culture conditions ( $2 \mathrm{~L}$ culture flasks with a media height of $10 \mathrm{~cm}$ ) and it remains to be seen how the cultures would perform on a larger scale within a pond or bioreactor.

The neutral lipid production of the cultures showed variations based on treatment. The FFA and TAG production from geothermal microalgal consortia, with and without secondary treatment, ranged from 0 to $38.74 \mathrm{mg} \mathrm{L}^{-1} \mathrm{day}^{-1}$. Zhou et al. (2011) investigated the lipid productivity of 17 strains, mainly Chlorella sp. (incubated at unknown temperature) and reported values ranging between 0.0369 and $94.8 \mathrm{mg} \mathrm{L}^{-1} \mathrm{day}^{-1}$, with an average lipid productivity of $54.97 \mathrm{mg} \mathrm{L}^{-1}$ day $^{-1}$. Mata et al. (2010) reported values of lipid productivity for 29 strains that ranged from 10.3 to $142.0 \mathrm{mg} \mathrm{L}^{-1} \mathrm{day}^{-1}$. Lipid production from the microalgal consortia was affected by the addition of bicarbonate and for some cultures by a temperature drop, with the exception of the $40^{\circ} \mathrm{C}$ cultures. The addition of bicarbonate in the lower temperature experiment (that came from the $30^{\circ} \mathrm{C}$ cultures), did not increase
TAG and FFA accumulation. This lack of accumulation could have been due to increased $\mathrm{CO}_{2}$ solubility at lower temperatures rendering the additional carbon source unnecessary. In the $40^{\circ} \mathrm{C}$ culture the lower temperature experiment (with and without the addition of bicarbonate) showed reduced TAG and FFA content; this could have been due to general loss in culture biomass. Adequate dissolved inorganic carbon must be present for new lipid synthesis from carbon fixation. Inorganic carbon (in the form of bicarbonate) was supplied because it is an effective lipid accumulation trigger that induces carbon storage metabolic activity (Gardner et al., 2012, 2013; White et al., 2013). Although the addition of bicarbonate increased lipid productivity, values were still in the lower range of those reported for algal strains. Unfavorable growth conditions can cause a cessation of cellular replication and thereby also increasing the accumulation of FFA and TAG (Renaud et al., 1991; Sheehan et al., 1998; Widjaja et al., 2009). The highest values of FFA and TAG production were seen in the Hazen cultures, with a shift to $15^{\circ} \mathrm{C}$ with and without the addition of bicarbonate, and were approximately $6 \%$ of the biomass produced. The neutral lipid production in these cultures was most likely due to the presence of Achnanthidium sp.; however, these values were still below the average of the reported values for oleaginous strains.

The composition of FFA and TAG were also affected by the temperature decrease. FFA and TAG compositions followed the general trend of increasing unsaturation with decreasing temperature (Hu et al., 2008). The S/U ratio (the saturated to unsaturated FA ratio) decreased for cultures shifted from their original temperature to $15^{\circ} \mathrm{C}$ : (1) from 2.62 to 0.22 at $30^{\circ} \mathrm{C}$, (2) from 1.69 to 0.41 at $35^{\circ} \mathrm{C}$, and (3) from 5.61 to 1.89 at $40^{\circ} \mathrm{C}$. Cultures from both 30 and $35^{\circ} \mathrm{C}$, when shifted to $15^{\circ} \mathrm{C}$, increased in palmitoleic acid (C16:1) content. A desaturation of palmitic acid to palmitoleic acid has been seen in Anabaena variabilis (Sato and Murata, 1980). The trend toward a decrease in chain length and an increase in unsaturation is based on maintaining membrane fluidity at cooler temperatures (Cronan and Gelmann, 1975; McElhaney and Souza, 1976; Hochachka and Somero, 1984). Triacylglycerides diversity increased by the end of the incubation period in all cultures and the trend of decreased chain length and increased unsaturation was seen at cooler temperatures.

The degree of unsaturation and common chain length of the FFAs found in the geothermal microalgal consortia were suitable for biodiesel production (Leonardi et al., 2011). The content of linolenic acid in all cultures - before and after secondary treatment - was below $12 \%(\%, \mathrm{~m} / \mathrm{m})$, which is the maximum allowed by the European standard EN 14214. The most common chain length for polyunsaturated fatty acid (PUFA) was 16, with a maximum of 20 .

The biomass production rates reported in this study show the potential of consortia as a source of alternative energy. Biomass production was within the upper limits of those reported for individual strains. Production of neutral lipids was increased with secondary treatment but still not comparable with oleaginous strains. Further work needs to be done on various high-temperature, microalgal consortia to establish the expected range for consortia production rates. 


\section{AUTHOR CONTRIBUTIONS}

Kathryn F. Bywaters: conception of experimental design, performed experiments, post processed and analysed of data, and drafted the paper. Christian H. Fritsen: conception of experimental design, analysis of data, and drafted the paper.

\section{ACKNOWLEDGMENTS}

This research was supported by the Department of Energy DEEE0000600. We would like to thank Dr. Samburova and Dr. Zielinska for the FFA and TAG analysis, William Coloumbe for aiding with Ecopod operations and Eric Wirthlin, Jeramie Memmott, Clinton Davis, Teresa Schwedhelm, and Emily Ulrich for lab assistance.

\section{REFERENCES}

Aishvarya, V., Pradhan, N., Nayak, R. R., Sukla, L. B., and Mishra, B. K. (2012). Enhanced inorganic carbon uptake by Chlorella sp. IMMTCC-2 under autotrophic conditions for lipid production and $\mathrm{CO} 2$ sequestration. J. Appl. Phycol. 24, 1455-1463. doi:10.1007/s10811-012-9801-9

Araujo, G. S., Matos, L., Goncalves, L. R. B., Fernandes, F. A. N., and Farias, W. R. L. (2011). Bioprospecting for oil producing microalgal strains: evaluation of oil and biomass production for ten microalgal strains. Bioresour. Technol. 102, 5248-5250. doi:10.1016/j.biortech.2011.01.089

Bird, M. I., Wurster, C. M., De Paula Silva, P. H., Bass, A. M., and De Nys, R. (2011). Algal biochar - production and properties. Bioresour. Technol. 102, 1886-1891. doi:10.1016/j.biortech.2010.07.106

Bird, M. I., Wurster, C. M., De Paula Silva, P. H., Paul, N. A., and De Nys, R. (2012). Algal biochar: effects and applications. Glob. Change Biol. Bioenergy 4, 61-69. doi:10.1111/j.1757-1707.2011.01109.x

Brennan, L., and Owende, P. (2010). Biofuels from microalgae - a review of technologies for production, processing, and extractions of biofuels and co-products. Renew. Sustain. Energ. Rev. 14, 557-577. doi:10.1016/j.rser.2009.10.009

Brock, T. D. (1967). Micro-organisms adapted to high temperatures. Nature 214, 882. doi:10.1038/214882a0

Carroll, J. J., Slupsky, J. D., and Mather, A. E. (1991). The solubility of carbondioxide in water at low-pressure. J. Phys. Chem. Ref. Data 20, 1201-1209. doi:10.1063/1.555900

Clesceri, L. S., Greenberg, A. E., and Eaton, A. D. (eds) (1998). Standard Methods for the Examination of Water and Wastewater. Baltimore, MD: American Public Health Association, American Water Works Association, Water Environment Federation.

Cronan, J. E., and Gelmann, E. P. (1975). Physical-properties of membrane lipids biological relevance and regulation. Bacteriol. Rev. 39, 232-256.

Davis, C. J. (2012). Periphyton Ecology in Great Basin Rivers: Winter Blooms, Hyporheic Exchange Effects, and Reservoir-Tailwater Productivity. Dissertation/Thesis, ProQuest, UMI Dissertations Publishing, Reno.

Dodds, W. S., Stutzman, L. F., and Sollami, B. J. (1956). Carbon dioxide solubility in water. Ind. Eng. Chem. Chem. Eng. Data Series 1,92-95. doi:10.1021/i460001a018

Faulds, J. E., Coolbaugh, M., Blewitt, G., and Henry, C. D. (2004). Why is Nevada in hot water? Structural controls and tectonic model of geothermal systems in the northwestern Great Basin. Geoth. Res. Council Trans. 28, 649-654.

Gardner, R., Cooksey, K., Mus, F., Macur, R., Moll, K., Eustance, E., et al. (2012). Use of sodium bicarbonate to stimulate triacylglycerol accumulation in the chlorophyte Scenedesmus sp. and the diatom Phaeodactylum tricornutum. J. Appl. Phycol. 24, 1311-1320. doi:10.1007/s10811-011-9782-0

Gardner, R. D., Lohman, E., Gerlach, R., Cooksey, K. E., and Peyton, B. M. (2013). Comparison of $\mathrm{CO} 2$ and bicarbonate as inorganic carbon sources for triacylglycerol and starch accumulation in Chlamydomonas reinhardtii. Biotechnol. Bioeng. 110, 87-96. doi:10.1002/bit.24592

Giordano, M., Beardall, J., and Raven, J. A. (2005). CO2 concentrating mechanisms in algae: mechanisms, environmental modulation, and evolution. Annu. Rev. Plant Biol. 56, 99-131. doi:10.1146/annurev.arplant.56.032604.144052

Hochachka, P. W., and Somero, G. N. (1984). Biochemical Adaptation. Princeton, NJ: Princeton University Press.

Hu, Q., Sommerfeld, M., Jarvis, E., Ghirardi, M., Posewitz, M., Seibert, M., et al. (2008). Microalgal triacylglycerols as feedstocks for biofuel production: perspectives and advances. Plant J. 54, 621-639. doi:10.1111/j.1365313X.2008.03492.x

Huerlimann, R., De Nys, R., and Heimann, K. (2010). Growth, lipid content, productivity, and fatty acid composition of tropical microalgae for scale-up production. Biotechnol. Bioeng. 107, 245-257. doi:10.1002/bit.22809

Kim, W. (2011). Optimization of culture conditions and comparison of biomassproductivity of three green algae. Bioprocess Biosyst. Eng. 35, 19-27. doi:10.1007/s00449-011-0612-1

Leonardi, P. I., Popovich, C. A., and Damiani, M. C. (2011). "Feedstocks for secondgeneration biodiesel: microalgae's biology and oil composition" in Economic effects of biofuel production. ed. M. A. dos Santos Bernardes (Croacia: In Tech), 318-346. doi:10.5772/23125

Liao N (2002). Determination of Orthophosphate in Waters by Flow Injection Analysis Colorimetry. QuikChem ${ }^{\circledR}$ Method 10-115-01-1-M:17. Loveland, CO: LaChat Instruments.

Mata, T. M., Martins, A. A., and Caetano, N. S. (2010). Microalgae for biodiesel production and other applications: a review. Renew. Sust. Energy Rev. 14, 217-232. doi:10.1016/j.rser.2009.07.020

McElhaney, R. N., and Souza, K. A. (1976). The relationship between environmental temperature, cell growth and the fluidity and physical state of the membrane lipids in Bacillus stearothermophilus. Biochim. Biophys. Acta 443, 348-359. doi:10.1016/0005-2787(76)90499-8

Murray, K. E., Shields, J. A., Garcia, N. D., and Healy, F. G. (2012). Productivity, carbon utilization, and energy content of mass in scalable microalgae systems. Bioresour. Technol. 114, 499-506. doi:10.1016/j.biortech.2012.03.012

Pritzlaff, P. (2000). Determination of Nitrate/Nitrite in Surface and Wastewaters by Flow Injection Analysis. QuikChem ${ }^{\circledR}$ Method 10-107-04-1-C-15. Loveland, CO: LaChat Instruments.

Prokopy, W. R. (2003). Determination of Ammonia by Flow Injection Analysis. QuikChem ${ }^{\circledR}$ Method 10-107-06-2-C - 10. Loveland, CO: LaChat Instruments.

Renaud, S., Parry, D., Thinh, L.-V., Kuo, C., Padovan, A., and Sammy, N. (1991). Effect of light intensity on the proximate biochemical and fatty acid composition of Isochrysis sp. and Nannochloropsis oculata for use in tropical aquaculture. J. Appl. Phycol. 3, 43-53. doi:10.1007/BF00003918

Samburova, V., Lemos, M., Hiibel, S., Kent Hoekman, S., Cushman, J., and Zielinska, B. (2013). Analysis of triacylglycerols and free fatty acids in algae using ultraperformance liquid chromatography mass spectrometry. J. Am. Oil Chem. Soc. 90, 53-64. doi:10.1007/s11746-012-2138-3

Sato, N., and Murata, N. (1980). Temperature shift-induced responses in lipids in the blue-green alga, Anabaena variabilis: the central role of diacylmonogalactosylglycerol in thermo-adaptation. Biochim. Biophys. Acta 619, 353-366. doi:10.1016/0005-2760(80)90083-1

Sheehan, J., Dunahay, T., Benemann, J., and Roessler, P. (1998). A Look Back at the U.S. Department of Energy's Aquatic Species Program - Biodiesel from Algae. Golden, CO: National Renewable Energy Laboratory. Report NREL/TP-580-24190.

Smith, R. G., and Bidwell, R. (1989). Mechanism of photosynthetic carbon dioxide uptake by the red macroalga, Chondrus crispus. Plant Physiol. 89, 93-99. doi:10.1104/pp.89.1.93

Stephenson, P. G., Moore, C. M., Terry, M. J., Zubkov, M. V., and Bibby, T. S. (2011). Improving photosynthesis for algal biofuels: toward a green revolution. Trends Biotechnol. 29, 615-623. doi:10.1016/j.tibtech.2011.06.005

Terry, K. L., and Raymond, L. P. (1985). System-design for the autorophic production of microalgae. Enzyme Microb. Technol. 7, 474-487. doi:10.1016/01410229(85)90148-6

United States Congress Senate Committee On, E., Natural Resources Subcommittee On, E., and Mineral, R. (1984). Geothermal Energy Development in Nevada's Great Basin: Hearing Before the Subcommittee on Energy and Mineral Resources of the Committee on Energy and Natural Resources, United States Senate, NinetyEighth Congress, Second Session, to Examine the Current Status and Future Needs of Nevada's Geothermal Energy Industry, Sparks, NV, April 17, 1984. Washington, DC: U.S. G.P.O.

Weissman, J. C., and Benemann, J. R. (1979). Biomass recycling and species competition in continuous cultures. Biotechnol. Bioeng. 21, 627-648. doi:10.1002/bit. 260210408

White, D. A., Pagarette, A., Rooks, P., and Ali, S. T. (2013). The effect of sodium bicarbonate supplementation on growth and biochemical composition of marine microalgae cultures. J. Appl. Phycol. 25, 153-165. doi:10.1007/s10811012-9849-6 
Widjaja, A., Chien, C. C., and Ju, Y. H. (2009). Study of increasing lipid production from fresh water microalgae Chlorella vulgaris. J. Taiwan Inst. Chem. Eng. 40, 13-20. doi:10.1016/j.jtice.2008.07.007

Wolters, M. (2002). Determination of Silicate in Brackish or Seawater by Flow Injection Analysis. QuikChem ${ }^{\circledR}$ Method 31-114-27-1-D - 12. Loveland, CO: LaChat Instruments.

Zhou, W. G., Li, Y. C., Min, M., Hu, B., Chen, P., and Ruan, R. (2011). Local bioprospecting for high-lipid producing microalgal strains to be grown on concentrated municipal wastewater for biofuel production. Bioresour. Technol. 102, 6909-6919. doi:10.1016/j.biortech.2011.04.038

Conflict of Interest Statement: The Guest Associate Editor Umakanta Jena declares that, despite being affiliated to the same institution as authors, the review process was handled objectively and no conflict of interest exists. The authors declare that the research was conducted in the absence of any commercial or financial relationships that could be construed as a potential conflict of interest.

Received: 29 August 2014; accepted: 13 December 2014; published online: 16 February 2015.

Citation: Bywaters KF and Fritsen CH (2015) Biomass and neutral lipid production in geothermal microalgal consortia. Front. Bioeng. Biotechnol. 2:82. doi: 10.3389/fbioe.2014.00082

This article was submitted to Bioenergy and Biofuels, a section of the journal Frontiers in Bioengineering and Biotechnology.

Copyright $(0) 2015$ Bywaters and Fritsen. This is an open-access article distributed under the terms of the Creative Commons Attribution License (CC BY). The use, distribution or reproduction in other forums is permitted, provided the original author (s) or licensor are credited and that the original publication in this journal is cited, in accordance with accepted academic practice. No use, distribution or reproduction is permitted which does not comply with these terms. 